Published on Reviews in History (https://reviews.history.ac.uk)

\title{
French Revolution review article
}

Review Number: 1783

Publish date: Thursday, 25 June, 2015

Author: Rebecca Spang

ISBN: 9780674047037

Date of Publication: 2015

Price: $£ 25.00$

Pages: 360pp.

Publisher: Harvard University Press

Publisher url: http://www.hup.harvard.edu/catalog.php?isbn=9780674047037

Place of Publication: Cambridge, MA

Author: Timothy Tackett

ISBN: 9780674736559

Date of Publication: 2015

Price: $£ 25.00$

Pages: 480pp.

Publisher: Harvard University Press

Publisher url: http://www.hup.harvard.edu/catalog.php?isbn=9780674736559

Place of Publication: Cambridge, MA

Reviewer: Dave Andress

French revolutionary money is funny stuff. In my own collection I have a five-sous coin that is little short of a work of art, a handsome bronze disc with a veritable bas-relief of revolutionary symbolism - yet this was produced not by the state, but as a private token, a medaille de confiance, one of a proliferation of initiatives to relieve the shortage of small change, in this case by the Monneron Brothers bank. What is more, it was coined not in Paris, but Birmingham, at Matthew Boulton's revolutionary steam-powered Soho mint. I have another coin that is very much the official product of the French state - marked 'République française' and the year, 1793, made in a yellowish metal quite possibly the product of melted church bells. Yet it bears the likeness of Louis XVI, probably already dead by the time it was struck, and shows other signs of having been worn as a medallion in his memory.

Both objects point to the central historical dilemma discussed directly by Rebecca Spang, and in a looser sense also by Timothy Tackett - how could people in revolutionary times know how to trust everyday social interactions, when the signs and symbols of the cultural landscape that inscribed meaning into such interactions were endlessly displaced? And how were they supposed to feel about this situation?

Tackett's approach is to give us an essentially narrative history of the years running up to and into what is loosely regarded as 'the Terror'. As its title indicates, Tackett's book is much more concerned with how the dramatic events of 1793-4 became possible than with how, in detail, they played out. Thus Robespierre joins the Committee of Public Safety on p. 292 of Tackett's account, and is executed, a year later, on p. 339, with events after that relegated to general conclusions. His approach is shaped by the choice of sources he developed with great success in his work, some 20 years ago, on the men who sat in the National Assembly 
of 1789-91.(1) The book thus leans heavily on personal accounts and observations captured from a wide array of correspondence and diaries. Although the collection of material is impressive, Tackett himself acknowledges that, for the most part, this confines his key witnesses to 'that exclusive group' of some oneto-two per cent of the population who were the products of a full secondary education, and made up the leadership cadre of politics (p. 16).

Spang's work is very different, picking up and developing the close reading of different forms of evidence and innovative reflection on layers of social experience that characterised her earlier book on the history of the restaurant.(2) Much more a conventional monograph in conception than Tackett's, it nonetheless also conveys a strong sense of the changing phases of revolutionary attitudes to money, and out of that key issue, draws wide-ranging reflections on the nature of the revolutionaries' culture - and thus, on what they were capable of understanding as 'political' and 'economic'. Whereas Tackett's book is full of previouslyunknown individual observations on events well known to historians, Spang's raises the lid on a whole array of revolutionary social relations and political dilemmas that have previously lacked their historian, and thus poses fascinating new questions about how to understand the wider processes of life in the 1790s.

We are taken on a journey that reminds us that trust is central to the very concept of money - that in the Old Regime the monarchy could change the value of supposedly 'secure' gold and silver coins by fiat, and often did; that small-change rarely had any 'intrinsic' value, and what was in circulation could be so worn as to be indistinguishable from the corroded flattened nail-heads that sometimes circulated alongside it. In a situation where people trusted the continuity of monetary value, these things did not really matter, as it did not really matter that the state rarely issued new coins, but private individuals could take silver and gold objects to a number of privileged local mints and have them turned into coins to order. Nor did it matter that accounts were kept in a system that had no one-to-one correlation with any existing unit of metallic currency, or that, for most people most of the time, business was done on a continuously-circulating system of credit, and most monetary instruments were private bills of exchange, bonds and promissory notes from a wide range of non-state and sub-state institutions.

Spang explores in detail how revolutionary politicians persuaded themselves that patriotic confidence ought to be able to substitute for the habits that had held old-regime monetary practices together, while developing their own peculiar ideas about what constituted the function of money. Since the whole premise of the revolution was the fiscal and financial incompetence of the state, and since the revolutionaries in late 1789 had taken an enormous political and social gamble in seizing control of the lands of the Catholic Church to put material collateral behind their plans for stabilisation, all this was of critical import.

As the revolutionary credit-notes issued on the basis of those lands, the assignats, journeyed from being something very like an asset-backed bond to something very like money, legislators stubbornly resisted any idea of making them exclusive legal tender, or of compelling their face-value acceptance. With coinage in drastic short supply and revolving credit no longer an option in chaotic times, privately- or locally-issued billets de confiance and, as above, metallic monnaie de confiance entered circulation in vast, unverifiable quantities, turning the monetary realm into one of ever-shifting boundaries of individual decision-making for people at every social level. Was this particular piece of paper, this specific coin, actually worth anything at all; what was the difference between a real assignat, a forged one (and I once saw one in the police archives that was hand-drawn), and a billet de confiance that was no more than a few words printed on paper, signed by a local mayor or councilman? Do you trust the person who has given it to you, and what do you do if you don't? Money, that ought to have been the crucial lubricant of socio-economic interaction, became instead a source of friction that locked basic everyday realities into the highest levels of political conflict.

Belief amongst the elite that an economic free market ought to secure the value of their paper instruments coincided with arduous efforts to produce assignats that were physically worthy of confidence, and resistant to forgery. Alongside such efforts ran also the abiding conviction that lack of confidence - and assignats already traded at 10-20 per cent below their face-value on the Parisian streets in early 1791 - was a political situation, evidence of counter-revolutionary plotting and treasonous intention. Voices from the popular 
radical clubs demanded the simple solution of cours forcé - to make the assignats 'fiat money', traded at face-value under criminal sanction, but the legislators could never go this far, only banning private billets de confiance at the very end of 1792, and not until April 1793, after a year of wartime disasters, attempting to implement a cours forcé which never fully took hold. Printing ever-larger volumes of assignats took the place of failings in other means of public finance - and also required a massive workforce, beset with internal rivalries and political denunciations - but as Spang also intriguingly shows, the fall in their value was never understood as an 'inflation' in the modern sense, being always related back to essentially political and material questions of their substance, and citizens' beliefs about them.

In the course of laying this out, and taking the story through to the supposed Napoleonic stabilisation, and continued battles over the physical nature of the currency into the 1840s, Spang also leads us repeatedly from the high-toned debates of legislators to the lives of citizens, afflicted in every town and village by radical disruptions to their economic life. One of the great virtues of the book is its persistent reminders that decisions taken at the political centre had real consequences for millions of individual lives, and that all of those individuals had their own concerns, alarms, and conclusions about the politics of money. When the last desperate gasp of independent Parisian popular radicalism played itself out in the doomed sans-culotte insurrections of the Spring of 1795, their demands for 'bread' embraced also the means to pay for it: bread existed, but the money to buy it with was evaporating before their eyes - older assignats 'demonetized' by decree, newer ones scorned by shopkeepers.

Pairing the hard materialism of a study of what money actually was as objects with a sensitive attunement to what people thought and felt about such objects, and the cultural implications they held, Spang convincingly denies any easy separation between 'emotional' and 'rational' realms of politics and economics. All are placed together in a social world that was at the time frequently chaotic, but which emerges from the pages of this book newly illuminated.

While Spang ventures onto the territory of the history of emotions in bringing her insights together, Tackett wishes to place an emotional understanding of revolutionary politics at the heart of his story. However, of the two he is less successful at making the case for this as an innovative insight. Although in his introduction he claims to be going beyond a generalised account of 'sentiment', naming William Reddy and Sophie Wahnich (p. 7) as touchstones of what is to be surpassed, his central argument concerns fear and anxiety, understood in supposedly unproblematic terms. Furthermore, given the nature of his source-base, a great deal of the reflection on such emotions comes either in self-description or in the attribution of more or less 'irrational' sentiments to enemies, opponents, or the mob.

Two essential difficulties present themselves here. In the matter of self-description, one of the key aspects of Reddy's work on sentimentalism in this period is that it is not discursively transparent, and that various forms of introspective and private communicative practices had in fact culturally-structured significance that was particular to the era.(3) People of that age did not understand the experience of strong feeling in the same way as is common now, attributing it to entirely different physiological and psychological mechanisms than our post-Freudian, post-traumatic age, with entirely different implications for the moral status of the 'feeler'. Thus to move towards a reflection on what such accounts mean requires an attention to metacognition - to thinking about thinking about feeling - which Tackett does not enter into.(4) One cannot simply take expressions of interiority, translate them into contemporary English, and deploy them as effective windows into the soul of the 1790s.(5) We may be assured that of course people were afraid and anxious amidst political chaos and frequent bloody violence, but how they processed those 'raw' apprehensions into self-awareness, and what that meant when consciously recorded in journals or letters, is quite another matter. $\underline{(6)}$

The second issue is that of the socio-cultural structure of Tackett's source-base. It has led him into a situation where, from the earliest pages of the text, 'popular' activity, and 'popular violence' in particular, is viewed from outside. A three-and-a-half-page section of his first chapter discusses the identity of 'the people' (pp. 22-6), over a page of which is concerned with the 'clear propensity for the use of violence that 
shocked and disconcerted the future Revolutionaries' (p. 24), and half a page more records expressions of scorn for popular ignorance. Although Tackett works hard to avoid simply repeating such prejudices in his narrative, they inevitably colour it, as dramatic popular actions are juxtaposed to vivid expressions of bourgeois feeling about such actions. The choice to present a narratively-structured history, and to base it on the particular kinds of sources he has uncovered, leaves Tackett effectively forced to look at the great popular engagements of the revolutionary era - the writing of the cahiers de doléances, the Parisian mobilisation of July 1789, the 'Great Fear', endemic anti-seigneurial petitioning and local direct action on feudal dues and taxation, great energetic risings both for and against the Parisian agenda across the country as all basically faceless and formless, something that happened to 'Revolutionaries', rather than being the expression of how far ordinary people were revolutionaries, or indeed, consciously and willingly counterrevolutionary.

Tackett's book is a vividly-written narrative history of revolutionary politics as a process that is not one of colliding social blocs or ideological leading elements, but of colliding preconceptions and a muddle of good intentions, choking fears and outbursts of dreadful, destructive suspicions. If he cannot say as much as he hopes about the real meaning of his witnesses' sentiments, he shows us very clearly how, in the minds of the educated elite, patterns of belief in conspiracy and betrayal were built up from a veritable mille-feuille of daily interactions, rumours, events and speculations. In focusing attention so much on the years running into what is generally called 'the Terror', he usefully reminds us of how much there is to understand beyond seeing that later period as an inescapable Black Hole, generating a predetermined gravitational acceleration of horror.

The book's weakness, ironically, is its concern to be monographically original, and to use a particular kind of source that precludes taking more of a panoramic view of the whole landscape of political interactions. On several occasions I was struck with the thought that - on the 1789 National Assembly, on the 1791 Oath of the Clergy, on the origins of the 1793 War in the Vendée - Tackett has over his long and distinguished career written better social history of those events than he offers here. Nonetheless, for the general or student reader, I would certainly recommend The Coming of the Terror as a fount of useful chronological clarity on the Revolution's political history.

For the more advanced or specialised reader, however, I give a wholehearted recommendation to read Stuff and Money at your earliest opportunity. Rebecca Spang has given us a work which appears to be much more narrowly focused than Tackett's, but which in practice asks an even more penetrating set of questions about the general issue of how we should understand social experience and its political consequences in the French Revolution, and beyond.

\section{Notes}

1. Timothy Tackett, Becoming a Revolutionary: The Deputies of the French National Assembly and the Emergence of a Revolutionary Culture (1789-1790) (Princeton, NJ, 1996). Back to (1)

2. Rebecca L. Spang, The Invention of the Restaurant: Paris and Modern Gastronomic Culture (Cambridge, MA, 2000). Back to (2)

3. William M. Reddy, The Navigation of Feeling; A Framework for the History of Emotions, (Cambridge, 2001). See also David J. Denby, Sentimental Narrative and the Social Order in France, 1760-1820 (Cambridge, 1994).Back to (3)

4. Anne C. Vila, Enlightenment and Pathology; Sensibility in the Literature and Medicine of EighteenthCentury France (Baltimore, MD, 1998); Jessica Riskin, Science in the Age of Sensibility; the Sentimental Empiricists of the French Enlightenment (Chicago, IL, 2002). Cf. Sarah Knott, Sensibility and the American Revolution (Chapel Hill, NC, 2009). Back to (4)

5. For a general discussion of the history of emotions and its methodologies, see the recent review here: < http://www.history.ac.uk/reviews/review/1752> [3] [accessed 22 April 2015].Back to (5) 
6. For wider discussions, see Barbara H. Rosenwein, 'Worrying about emotions in history', American Historical Review, 107 (2002), pp. 821-45; Monique Scheer, 'Are emotions a kind of practice (and is that what makes them have a history)? A Bourdieuian approach to understanding emotion', History and Theory, 51 (2012), pp. 193-220. Some of my own reflections on this topic are in David Andress, 'Living the revolutionary melodrama: Robespierre's sensibility and the construction of political commitment in the French Revolution', Representations, 114 (2011), 103-28. Back to (6)

\section{Other reviews:}

Spectator

http://www.spectator.co.uk/books/books-feature/9444992/when-the-money-ran-out-so-did-the-idealism-inpost-revolutionary-france/ [4]

LA Review of Books

http://lareviewofbooks.org/review/emotions-stupid [5]

Atlantic

http://www.theatlantic.com/magazine/archive/2015/05/terror-at-the-dawn-of-modern-europe/389552/ [6]

Financial Times

http://www.ft.com/cms/s/0/18a461dc-a7a4-11e4-be63-00144feab7de.html [7]

Source URL:https://reviews.history.ac.uk/review/1783

\section{Links}

[1] https://reviews.history.ac.uk/item/133387 [2] https://reviews.history.ac.uk/item/133388

[3] http://www.history.ac.uk/reviews/review/1752\&gt; [4] http://www.spectator.co.uk/books/booksfeature/9444992/when-the-money-ran-out-so-did-the-idealism-in-post-revolutionary-france/

[5] http://lareviewofbooks.org/review/emotions-stupid

[6] http://www.theatlantic.com/magazine/archive/2015/05/terror-at-the-dawn-of-modern-europe/389552/

[7] http://www.ft.com/cms/s/0/18a461dc-a7a4-11e4-be63-00144feab7de.html 